\title{
Comparison of Chemical Constituents of Chamomilla recutita (L.) Rauschert Essential Oil and its Anti- Chemotactic Activity
}

\author{
Mayra Marinho Presibella, Larissa De Biaggi Villas-Bôas, Klézia Morais da Silva Belletti, \\ Cid Aimbiré de Moraes Santos and Almeriane Maria Weffort-Santos \\ Programa de Pós-graduação em Ciências Farmacêuticas; Universidade Federal do Paraná; Av. Prefeito Lothário \\ Meissner, 632; Jd. Botânico; 80210-170; almeriane@ufpr.br; Curitiba - PR - Brasil
}

\begin{abstract}
Several essential oil samples from dried flower-heads of Chamomilla recutita (L.) Rauschert, grown and commercially available around Curitiba metropolitan area, South of Brazil, were analyzed by GC-MS and the chemical constituents were compared with an Egyptian sample obtained under similar conditions and used as a control. The local grown herbs showed levels of essential oil below the standards recommended by the Brazilian Pharmacopoeia. Also, differences in their composition as well as in the quantity of several components were found such as the unexpected inversion of the relative constitution of the A and $B \alpha$-bisabolol oxides. Of particular interest was the striking effect of the chamomile extracts upon human leukocyte chemotaxis, a biological anti-inflammatory activity not reported before, in which cell migration was in vitro inhibited at the same level as showed by dexamethasone.
\end{abstract}

Key words: Chamomilla recutita, Asteraceae, essential oil, chemotaxis, bisabolol oxide

\section{INTRODUCTION}

Chamomilla recutita (L.) Rauschert, Asteraceae, or simply chamomile, is one of the most popular and well documented herbal medicine whose flower-heads are used both internally and externally to alleviate or even to cure a vast list of disturbances (Blumenthal, 2000), particularly those related to inflammation conditions (Maiche et al., 1991; Lepley et al., 1996; Birt et al., 1997; Hernández-Ceruelos et al., 2002). Although used in different pharmaceutical preparations (Tubaro et al., 1984; Mann and Staba, 1986; Maiche et al., 1991; Fidler et al., 1996; Li et al., 1996), chamomile is mostly consumed as infusion for sedative and anxiolytic purposes (Viola et al., 1995; Cauffield and Forbes, 1999; Larzelere and Wiseman, 2002), as a digestive aid to treat gastrointestinal disturbances, specially in babies and small children (Weizman et al., 1993; De la Motte et al., 1997; Madisch et al., 2001), and in domestic medicine in wetting cotton pads for topical application with the aim of helping the healing of skin wounds and cuts (Mills and Bone, 2000).

In the last decade, the regional herbal medicine free market has been offering to consumers the possibility of purchasing chamomile dried flowerheads, produced around Curitiba metropolitan area, along with imported and more expensive

\footnotetext{
* Author for correspondence
} 
ones. Because herbal products can have differences in their composition depending on the soil where they grow (Salamon, 1992), and also may carry a variety of potential contaminating agents, such as pesticides, herbicides, heavy metals or even other herbal pharmaceuticals products that can cause toxicity or allergic reactions in sensitive persons (Stingeni et al., 1999), it is important to control all steps of their production to ensure that the final commercial products present the recommended characteristics by the specialized literature for pharmaceutical preparations. Therefore, they must present the potentially active chemical constituents described. In this context, it is worthy to note that formulations prepared from chamomile have been included in pharmacopoeias of at least 26 countries around the world (Salamon, 1992).

Although chamomile flower-heads have been produced in large scale in South of Brazil by several producers, there is no report concerning the compounds present in these marketed products. One of the aims of this work was to investigate and compare the chemical composition of some batches of chamomile produced locally. To achieve this, the essential oil composition of five samples from different producers purchased in the local herbal medicine free market were analyzed and compared with an Egyptian sample, which was used as a control as it had previously fulfilled all the Brazilian Pharmacopoeia recommendations. It was also questioned if these specimens could have potentially distinct biological effects. To address this question, the in vitro influence of the hydroethanolic extracts obtained from some of the final products were investigated on the chemotaxis of human leukocytes, one of the main steps of the body's inflammation response.

\section{MATERIAL AND METHODS}

\section{Plant material}

Six commercially available samples of dried Chamomilla recutita (L.) Rauschert flower-heads, five of them from plants grown in the metropolitan area of Curitiba, Paraná, Brazil, and one imported from Egypt for comparison, were purchased. Voucher specimens of each sample have been deposited at the Herbarium of the Laboratory of Pharmacognosy, Pharmacy Department, Federal University of Paraná, Brazil.

\section{Essential oil extraction}

Each sample $(250 \mathrm{~g})$ was subjected to $4 \mathrm{~h}$ hydrodistillation using a Clevenger apparatus and the recovered blue colored oils were dried over anhydrous sodium sulphate and kept at $4^{\circ} \mathrm{C}$ in sealed brown vials until analysis.

\section{Plant extract preparation}

Each sample $(50 \mathrm{~g})$ was extracted for $48 \mathrm{~h}$ at room temperature in a percolator containing $20 \%$ ethanol $(200 \mathrm{ml})$. The obtained extracts were filtered, concentrated under reduced pressure to dryness, re-suspended into Dulbecco's PBS, filtersterilized $(0.22 \mu \mathrm{m})$, aliquoted, and kept frozen at temperature $-20^{\circ} \mathrm{C}$ up to their utilization.

\section{Essential oil analysis}

GC-MS analyses were carried out with a HP 6890 Hewlett-Packard gas chromatographer coupled with mass spectroscopy (GC-MS), equipped with 5\% phenyl/95\% methylsiloxane (HP-5MS) capillary column (L: $30 \mathrm{~mm}$ x I.D.: $0.25 \mathrm{~mm}$, Ft.: $0.25 \mu \mathrm{m})$. The temperature programming condition was $40-250^{\circ} \mathrm{C}$ at $4^{\circ} \mathrm{C} / \mathrm{min}$ initial temperature; Helium at $0.8 \mathrm{ml} / \mathrm{min}$ was used as a carrier gas; $0.2 \mu 1$ of oil injection; $280^{\circ} \mathrm{C}$ transfer line temperature; $230^{\circ} \mathrm{C}$ ion source temperature; 1:200 splitting ratio; $70 \mathrm{eV}$ ionization energy; 50480 amu scan range; 2 s scan time.

\section{Components identification}

The identification of each compound in the analyzed oils was performed by comparison of the relative retention time (RT) and the mass spectral data were obtained from the literature (Jakovlev et al., 1979; Adams, 1995; Hernández-Ceruelos et al., 2002) along with the NIST 98 computerized MS-data bank.

\section{Human leukocytes isolation}

The protocol used in this work for human peripheral blood collection has been approved by the Clinical Hospital Ethical Committee of the Federal University of Paraná, CEP-HC No. 066EXT020/2002-11. Peripheral blood samples $(10 \mathrm{ml})$ in EDTA-K $\mathrm{K}_{3}$ were obtained by venipuncture from healthy volunteers after consent. Buffy coats were obtained after spinning the samples at $800 \mathrm{~g}$ for $25 \mathrm{~min}$ at room temperature and collecting the upper, leukocyterich fraction. Contaminating erythrocytes were removed by osmotic lysis with Gey's buffer 
(solution A: $\mathrm{NH}_{4} \mathrm{Cl} 654.20 \mathrm{mM} / \mathrm{l}, \mathrm{KCl} 24.83$ $\mathrm{mM} / 1, \quad \mathrm{Na}_{2} \mathrm{HPO}_{4} \cdot \mathrm{H}_{2} \mathrm{O} \quad 6.53 \mathrm{mM}, \quad \mathrm{KH}_{2} \mathrm{PO}_{4} 0.88$ $\mathrm{mM} / \mathrm{l}$, glucose $27.77 \mathrm{mM}$, phenol red $0.05 \mathrm{~g} / \mathrm{l}$; solution $\mathrm{B}: \mathrm{MgCl}_{2} \cdot 6 \mathrm{H}_{2} \mathrm{O} 2.06 \mathrm{mM}, \mathrm{MgSO}_{4} \cdot 7 \mathrm{H}_{2} \mathrm{O}$ $0.56 \mathrm{mM}, \mathrm{CaCl}_{2} 3.42 \mathrm{mM}$; solution $\mathrm{C}: \mathrm{NaHCO}_{3}$ $26.78 \mathrm{mM}$, all at $\mathrm{pH}$ 7.2-7.4; just before use, $4: 1: 1$ parts of solutions $\mathrm{A}, \mathrm{B}$, and $\mathrm{C}$ were, respectively, added to 14 parts of $\mathrm{H}_{2} 0$, filter-sterilized, and kept at room temperature). After washing twice in PBS, the remaining leukocytes were resuspended into PBS supplemented (PBSS) with glucose $(0.1 \%$ $\mathrm{w} / \mathrm{v})$, BSA $(0.25 \% \mathrm{w} / \mathrm{v}), \mathrm{CaCl}_{2}(0.90 \mathrm{mM})$, and $\mathrm{MgCl}_{2}(0.5 \mathrm{mM})$, and the cell concentration was adjusted to $10^{6} / \mathrm{ml}$. All cell preparations used contained $>95 \%$ viable cells as estimated by the trypan blue exclusion test. Granulocytes (neutrophils, eosinophils, and basophils) constituted the major leukocyte population (> 73\%), followed by mononuclear cells (lymphocytes and monocytes).

\section{Extracts and drugs' cytotoxicity}

Primary screening tests upon leukocytes measured with all tested concentrations of chamomile extracts and dexamethasone using the trypan blue exclusion test did not show any signs of cytotoxicity to the human leukocytes and their viability was always higher than $95 \%$, before and after the migration experiments.

\section{Leukocyte migration}

Leukocytes were incubated with increasing extract concentrations $\left(0.1-10^{3} \mu \mathrm{g} / \mathrm{ml}\right)$ for $30 \mathrm{~min}$ at $37^{\circ} \mathrm{C}$, washed twice with PBS, and resuspended into PBSS. Thereafter, migration of the treated cells towards casein was measured using a modified Boyden technique (Boyden, 1962). Briefly, the upper chamber was separated from the lower one by a $5 \mu \mathrm{m}$ pore size, PVP free polycarbonate filter (NeuroProbe) and loaded with $2 \times 10^{5}$ human leukocytes, which were stimulated to migrate towards $1 \%(\mathrm{w} / \mathrm{v})$ casein gradient placed into the lower chamber for $90 \mathrm{~min}$ at $37^{\circ} \mathrm{C}$. In some experiments, the cells were first pre-treated with dexamethasone (Decadron-Prodome; $10^{-5} \mathrm{M}$ ) or with increasing concentrations $\left(0.1-10^{3} \mu \mathrm{g} / \mathrm{ml}\right)$ of chamomile extracts, both at room temperature for $30 \mathrm{~min}$, before chemotaxis. Cell migration was expressed as a percentage of the control, i.e., the number of cells, which had not been treated with any plant extract, migrating towards chemoattractant under similar conditions. It is important to note that the experimental protocol used allowed only the migration of granulocytes, and cytospun preparations stained with MayGrunwald-Giemsa showed that $>95 \%$ of the migrated cells were neutrophils.

\section{Statistical evaluation}

The results are expressed as the mean $\% \pm$ SEM of migrated cells. Statistical significance was calculated by the $t$ test and differences were considered significant when $p \leq 0.05$.

\section{RESULTS}

The percentage of essential oil found for the Brazilian samples varied from 0.2 to $0.3 \%(\mathrm{v} / \mathrm{w})$, and it was $0.5 \%(\mathrm{v} / \mathrm{w})$ for the Egyptian control, showing that the local specimens were not in accordance with the standards required by the Brazilian Pharmacopoeia, which is at least $0.4 \%$ (v/w) (Farmacopéia, 1996). Table 1 shows the retention time (RT) and relative abundance (\%) of the essential oil constituents included in this study (only those in amounts higher than $0.1 \%$ ). The profile of the control sample was similar to those described in the literature (Jakolev et al., 1983; Scalia et al., 1999; Hernández-Ceruelos et al., 2002), and was used for comparison. Most of the known chamomile essential oil components such as $\beta$-farnesene (RT: 24.95), spathulenol (RT: 28.60), $\beta$-eudesmol (RT: 30.66), $\alpha$-bisabolol oxide B (RT: 30.81), $\alpha$-bisabolol (RT: 31.59) or $\alpha$ bisabolol oxide A (RT: 33.42), could be identified in all samples, although broad variation in their relative abundance was observed. Interestingly, chamazulene (RT: 32.79), one of the most important constituents of chamomile essential oil, was not detected in Sample 5 under the used experimental conditions.

The compounds $n$-hexadecanoic acid (RT: 38.85 ), $n$-hexadecanoic acid ethyl ester (RT: 39.38), and hexatriacontane (RT: 50.07), which have been reported as wax by Scalia and co-workers (Scalia et al., 1999), could be identified in the majority of the samples. On the other hand, $p$-cimene (RT: 10.35), n-decanoic acid ethyl ester (RT: 23.06), and trans-en-in-dicycloether (RT: 37.08) were detected only in the control, while the artemisia ketone (RT: 11.67) was present only in Sample 1. One of the most intriguing results of this work was related to the quantitative profile of the $\alpha$ - 
bisabolol oxides $\mathrm{A}$ and $\mathrm{B}$, in which a clear inversion was found, with the Brazilian samples presenting higher amounts of the B oxide, and lower amounts of A oxide, in relevant contrast with the values found for the control, which was in agreement with the literature (Scalia et al., 1999; Hernández-Ceruelos et al., 2002).
The effects of exposing human leukocytes from peripheral blood to increasing concentrations of a national (Sample 1) and the Egyptian chamomile extracts before inducing them to migrate towards a casein gradient are shown in Fig. 1.

Table 1 - GC-MS essential oil composition of different commercial samples of Chamomilla recutita (L.) Rauschert, Asteraceae, purchased at the herbal medicine free market in Curitiba (PR), Brazil.

\begin{tabular}{|c|c|c|c|c|c|c|c|c|}
\hline \multirow[b]{2}{*}{ RT } & \multirow[b]{2}{*}{ Compound* } & \multicolumn{7}{|c|}{$\%$ of relative abundance ${ }^{1}$} \\
\hline & & $\begin{array}{c}\text { Sample } \\
1\end{array}$ & $\begin{array}{c}\text { Sample } \\
2\end{array}$ & $\begin{array}{c}\text { Sample } \\
3\end{array}$ & $\begin{array}{c}\text { Sample } \\
4\end{array}$ & $\begin{array}{c}\text { Sample } \\
5\end{array}$ & $\begin{array}{l}\text { Egyptian } \\
\text { (control) }\end{array}$ & Ref. \\
\hline 9.64 & unknown & 0.48 & $<0.1$ & $<0.1$ & - & - & 0.41 & \\
\hline 10.35 & $p$-cimene & - & - & & - & - & 0.13 & \\
\hline 11.67 & artemisia ketone & 0.39 & - & & - & - & 0.63 & \\
\hline 15.38 & unknown & - & - & - & - & - & 0.12 & \\
\hline 22.74 & n-decanoic acid & - & 4.47 & & - & 1.55 & 5.55 & \\
\hline 23.06 & $n$-decanoic acid ethyl ester & - & - & & - & - & 0.84 & \\
\hline 24.95 & $\beta$-farnesene & 15.04 & 1.54 & 19.62 & 21,85 & 15.67 & 5.55 & $2,3,4$ \\
\hline 25.30 & unknown & 3.21 & 3.21 & 3.01 & 4.92 & 3.94 & - & \\
\hline 26.41 & unknown & 0.68 & - & - & 0.69 & 0.94 & - & \\
\hline 28.60 & spathulenol & 3.67 & 1.62 & 0.80 & 1.72 & 2.75 & 3.03 & 2 \\
\hline 29.72 & unknown & 4.51 & 3.47 & 0.48 & 3.47 & 4.48 & 0.59 & \\
\hline 30.10 & unknown & 2.35 & 1.81 & 1.85 & 0.84 & 2.59 & 0.53 & \\
\hline 30.66 & $\beta$-eudesmol & 1.89 & 2.22 & 4.50 & 0.67 & 2.10 & 1.38 & \\
\hline 30.81 & $\alpha$-bisabolol oxide B & 25.56 & 30.78 & 31.52 & 32.99 & 25.31 & 9.87 & $2,3,4$ \\
\hline 30.93 & unknown & 4.79 & 3.33 & 2.81 & 3.32 & 3.67 & 1.96 & \\
\hline 31.59 & $\alpha$-bisabolol & 14.86 & 16.42 & 10.88 & 7.66 & 13.99 & 12.29 & $2,3,4$ \\
\hline 31.72 & unknown & - & 1.53 & - & - & 1.79 & - & \\
\hline 32.79 & chamazulene & 1.54 & 1.47 & 0.45 & 0.60 & - & 1.42 & $2,3,4$ \\
\hline 33.42 & $\alpha$-bisabolol oxide A & 11.61 & 13.60 & 16.57 & 15.77 & 14.90 & 46.55 & $2,3,4$ \\
\hline 36.74 & cis-en-in-dicycloether & 8.28 & 5.82 & - & - & 8.57 & 5.07 & 2 \\
\hline 37.08 & trans-en-in-dicycloether & - & - & & - & - & 0.67 & 2 \\
\hline 38.85 & $n$-hexadecanoic acid & 1.59 & 5.63 & 4.90 & 4.43 & 1.60 & $1.85^{\#}$ & \\
\hline 39.38 & $\begin{array}{l}n \text {-hexadecanoic acid ethyl } \\
\text { ester }\end{array}$ & $<0.1$ & $<0.1$ & & - & - & $0.41^{\#}$ & 2 \\
\hline 42.79 & unknown & - & 1.40 & - & - & - & 0.41 & \\
\hline 50.07 & hexatriacontane & 0.83 & 2.20 & - & - & 2.88 & $1.34^{\#}$ & $2,3,4$ \\
\hline $\begin{array}{l}\text { based or } \\
\text { Scalia e } \\
\text { Hernanc } \\
\text { Jacovle } \\
\text { *) listed } \\
\text { \#) identi }\end{array}$ & $\begin{array}{l}\text { ercentage of the area of each pe } \\
., 1999 \\
\text {-Ceruelos et al., } 2002 \\
979 \\
\text { ly those present in amounts }>0 \\
\text { d as wax by } 2\end{array}$ & one deter & ination & & & & & \\
\hline
\end{tabular}

The Brazilian plant extract resulted in an unexpected increased dose-related number of cells retained in the upper chamber compartment in comparison with untreated controls up to 10 $\mu \mathrm{g} / \mathrm{ml}$, the best result concentration, with only 65.8 $\pm 5.3 \%$ of the cells recovered from the lower chamber $(\mathrm{n}=15 ; \mathrm{p} \leq 0.005)$. When similar treatment was performed with the control sample, a significant inhibitory effect was also observed but it showed a different dose-response profile, in which a dose-related decreasing effect was observed. The maximum significant effect was at the concentration of $0.1 \mu \mathrm{g} / \mathrm{ml}$ of extract, the lowest dose tested, with only $65.9 \pm 4.3 \%$ of the cells recovered from the lower compartment $(\mathrm{n}=$ $8 ; \mathrm{p} \leq 0.005)$. For DEXA $\left(10^{-5} \mathrm{M}\right)$, which had the 
ability to inhibit the migration properties of leukocytes in vitro (Lomas et al., 1991; Zentay et al., 1999), and had been considered a model for this purpose, the value found using similar conditions was $69.1 \pm 6.2 \%(\mathrm{n}=17 ; \mathrm{p} \leq 0.005)$.

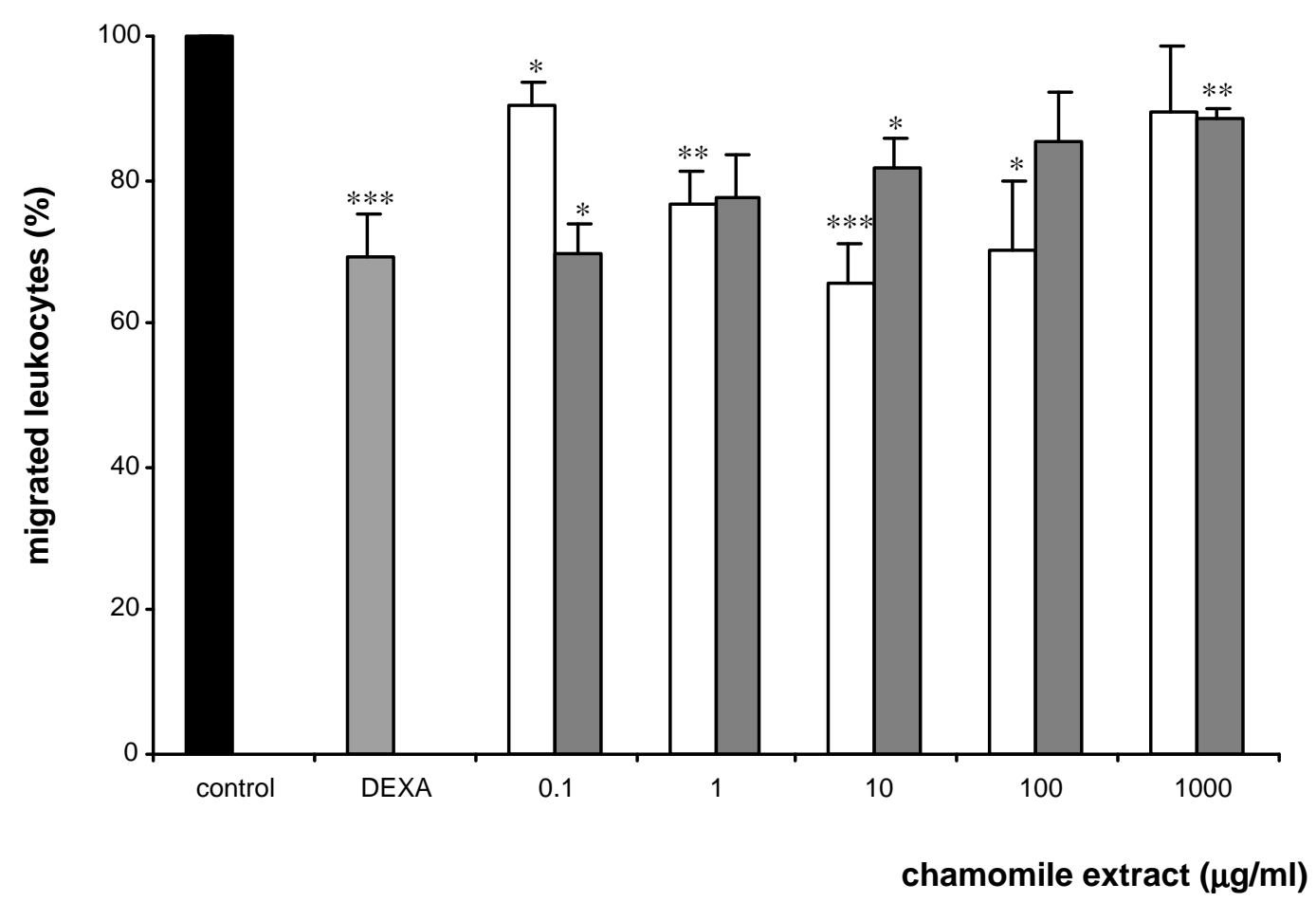

Figure 1 - Effect of chamomile extracts on casein-induced chemotactic activity of human leukocytes. Peripheral blood leukocytes obtained from healthy volunteers were pre-treated, for 30 minutes at room temperature, with DEXA $\left(10^{-5} \mathrm{M}\right)$ or with the Brazilian $(\square)$ or the Egyptian $(\square)$ chamomile extract at the indicated concentrations, and induced to migrate towards $1 \%$ casein gradient, for $90 \mathrm{~min}$ at $37^{\circ} \mathrm{C}$, in a Boyden system in which the compartments were separated by a $5 \mu \mathrm{m}$ pore size polycarbonate filter. Each column represents the mean $\% \pm$ SEM of total recovered cells from the lower compartment in relation to untreated cells (control), normalized at 100\%, from 8 to 17 individual experiments $(* \mathrm{p}<0.05 ; * * \mathrm{p}<0.025 ; * * * \mathrm{p}<0.0005)$.

\section{DISCUSSION}

Chamomile dried flower-heads are worldwide used to treat an extensive list of conditions (Blumenthal, 2000), varying from skin inflammation (Tubaro et al., 1984; Rekka et al., 1996; Brown and Dattner, 1998; Leung and Foster, 1998) to cancer (Maiche et al., 1991; Lepley et al., 1996; Birt et al., 1997; Hernández-Ceruelos et al., 2002), and several of its potentially biologicaly active chemical constituents have been isolated, specially those from its essential oil (Habersang et al., 1979; Jakolev et al., 1979; Jakolev et al., 1983; Safayhi et al., 1994; Gerritsen et al., 1995; Miller et al., 1996; Rekka et al., 1996; Avallone et al., 2000). The terpenoid chamazulene has been reported to affect the levels of protein upregulation at transcriptional level (Gerritsen et al., 1995; Rekka et al., 1996; Liang et al., 1999). Bisabolol, one of the most abundant components of the essential oil, apart from its spasmolytic effects on intestinal smooth muscle (AchterrathTuckermann et al., 1980; Forster et al., 1980), has been reported to have anti-inflammatory, antibacterial, antipyretic, antifungal properties (Berry, 1995; Blumenthal, 2000) as well as ulcerprotective effect (Isaac, 1979).

The data obtained from the GC-MS analysis showed clear and relevant differences in the chemical composition of the local samples when compared with the control. It was hypothesized whether these differences could affect the anti- 
inflammatory properties of these herbal plants. To address this question, a modified Boyden chamber system (Boyden, 1962) was used to test the ability of human leukocytes to migrate actively towards casein through a membrane in response to casein after their exposure to chamomile hydroethanolic extracts instead of using the essential oil. This approach was taken because, first, most if not all, essential oil constituents were present in the extract, and, second, because chamomile in this country has been largely consumed as a tea or infusion, and the extract would be the closest form to this traditional medicine use in the treatment of inflammatory conditions. Also, it would be worthy to note that this methodology has been extensively used as a model for investigating specific effects of plant extracts upon leukocyte locomotion (Muller et al., 1999; Hofbauer et al., 2000, 2001; Shen et al., 2001).

The biological data showed an unexpected and significant inhibition of the casein-induced polymorphonuclear leukocytes migration for both national and imported chamomile extracts tested. However, the intensity of such activity was distinct according to the dose and sample tested. For the local chamomile extract, the maximum inhibition effect observed was at the concentration of at least one hundred times higher than the value found for the imported sample under the experimental conditions used. Moreover, both effects were very close to the significant effects caused by DEXA, an anti-inflammatory drug commonly used in this system as a negative regulator of leukocyte chemotaxis (Lomas et al., 1991; Zentay et al., 1999).

These results could reflect the differences in their composition, some of which were revealed by the GC-MS analysis performed in this work. Moreover, they might be associated with the conditions in which these plants were produced, including all steps from the quality and preparation of the soil through the growing period, harvesting time, drying conditions to its presentation to the consumers at the free market, suggesting that surveillance on the quality control procedures must be taken when producing herbs, particularly for medicinal purposes.

Worthy of note in the present investigation was the significant inhibition of casein-induced human leukocyte chemotaxis by the chamomile extracts, suggesting that exposure of human leukocytes to chamomile was associated with impairment of leukocyte functions. Although the influence of chamomile or its compounds have been extensively investigated for inflammation processes using in vivo and in vitro approaches, to our knowledge there were no reports concerning to their influence on the chemotactic activity of human leukocytes, one of the most important steps of the body's inflammatory response.

While the cellular and molecular mechanisms involved remain obscure, the biological findings described in this study could be of particular relevance in clinical practice as at least a novel attractive hypothesis that could support the popular usage of chamomile infusions for combating inflammatory processes was revealed. By inhibiting the exacerbated leukocyte migration to the inflammation injury sites, chamomile could alleviate the symptoms and cope with wound healing produced by the inflammation process. Also, the intensity of such activity could be somewhat dependent on the quality of the medicinal plant used. Further analysis would be needed to clarify whether one or more of the known chamomile compounds were responsible for the inhibitory migration activity described in this work, or whether these effects were the result of the interaction of several compounds present in the extract, favoring the use of phytotherapic preparations.

\section{ACKNOWLEDGEMENTS}

One of us (L.D.B.V-B.) thanks CNPq for PIBIC scholarship.

\section{RESUMO}

Óleos essenciais extraídos de amostras de Chamomilla recutita (1.) Rauschert cultivadas e comercializadas na região metropolitana de Curitiba, sul do Brasil, foram analisadas por cromatografia com fase gasosa acoplada à espectrometria de massa e seus constituintes químicos comparados com uma amostra egípcia, usada como controle. A quantidade de óleo essencial obtida das amostras locais foi abaixo do padrão recomendado pela Farmacopéia Brasileira IV. Observou-se, também, diferenças na composição química desses óleos, assim como na quantidade relativa dos constituintes, como os óxidos A e B do $\alpha$-bisabolol. De particular 
interesse foram os efeitos inibidores dos extratos de camomila sobre a quimiotaxia de leucócitos humanos induzida por caseína, efeito biológico descrito pela primeira vez e semelhante ao promovido pela dexametasona.

\section{REFERENCES}

Achterrath-Tuckermann, U.; Kunde, R.; Flaskamp, E., Isaac; O. and Thiemer, K. (1980), Pharmacological investigations with compounds of chamomile. V. Investigations on the spasmolytic effect of compounds of chamomile and Kamillosan on the isolated guinea pig ileum. Planta Medica, 39, 38-50.

Adams, R. P. (1995), Identification of essential oil components by Gas Chromatography/Mass Spectroscopy. Illinois, Allured Publishing Corporation.

Avallone, R. P. Z.; Puia, G.; Kleinschnitz. M.; Schreier, P. and Baraldi, M. (2000), Pharmacological profile of apigenin, a flavonoid isolated from Matricaria chamomilla. Biochemical Pharmacology, 59, 1387-1394.

Berry, M. (1995), Herbal Products. Part 6. Chamomiles. Pharmacology Journal, 254, 191-193.

Birt, D. F.; Mitchell, D.; Gold, B.; Pour, P. and Pinch, H. C. (1997), Inhibition of ultraviolet light induced skin carcinogenesis in SKH-1 mice by apigenin, a plant flavonoid. Anticancer Research, 17, 85-91.

Blumenthal, M. (2000), The complete German commission and monographs. Therapeutic guide to herbal medicines. Austin, Texas, Integrative Medicine Communications.

Boyden, S. (1962), The chemotactic effect of mixtures of antibody and antigen on polymorphonuclear leucocytes. Journal of Experimental Medicine, 115, 453-466.

Brown, D. J. and Dattner, A. M. (1998), Phytotherapeutic approaches to common dermatologic conditions. Archives of Dermatolology 134, 1401-1404.

Cauffield, J. S. and Forbes, H. J. (1999), Dietary supplements used in the treatment of depression, anxiety, and sleep disorders. Lippincotts Primary Care and Practice, 3, 290-304.

De la Motte, S.; Bose-O'Reilly, S.; Heinisch, M. and Harrison, F. (1997), Double-blind comparison of an apple pectin-chamomile extract preparation with placebo in children with diarrhea. Arzneimittelforschung, 47, 1247-1249.

Farmacopéia Brasileira (1996), São Paulo: Atheneu. pp.13.

Fidler, P.; Loprinzi, C. L. and O'Fallon, J. R. (1996), Prospective evaluation of a chamomile mouthwash for prevention of 5-FU-induced oral mucositis. Cancer, 77, 522-525.
Forster, H. B.; Niklas, H. and Lutz, S. (1980), Antispasmodic effects of some medicinal plants. Planta Medica, 40, 309-319.

Gerritsen, M. E.; Carley, W. W.; Ranges, G. E.; Shen, C. P.; Phan, S. A.; Ligon, G. F. and Perry, C. A. (1995), Flavonoids inhibit cytokine-induced endothelial cell adhesion protein gene expression. American Journal of Pathology, 147, 278-292.

Habersang, S.; Leuschner, F.; Isaac, O. and Thiemer, K. (1979), Pharmacological studies with compounds of chamomile. IV. Studies on toxicity of (-)-alphabisabolol. Planta Medica, 37, 115-123.

Hernández-Ceruelos, A.; Madrigal-Bujaidar, E. and De La Cruz, C. (2002), Inhibitory effect of chamomile essencial oil on the sister chromatid exchanges induced by daunorubicin and methyl methanesulfonate in mouse bone marrow. Toxicology Letter, 135, 103-110.

Hofbauer, R.; Frass, M.; Gmeiner, B.; Kaye, A. D. and Frost, E. A. (2000), Garlic extract (Allium sativum) reduces migration of neutrophils through endothelial cell monolayers. Middle East Journal of Anesthesiology, 15, 649-658.

Hofbauer, R.; Frass. M.; Gmeiner, B.; Kaye, A. D. and Frost, E. A. (2001), Effects of garlic extract (Allium sativum) on neutrophil migration at the cellular level. Heart Disease, 3, 14-17.

Isaac, O. (1979), Pharmacological investigations with compounds of chamomile on the pharmacology of (-)-alpha-bisabolol and bisabolol oxides (review). Planta Medica, 35, 118-124.

Jakolev, V.; Isaac, O. and Flaskamp, E. (1983), Pharmacological investigations with compounds of chamomile. VI. Investigations on the antiphlogistic effects of chamazulene and matricine. Planta Medica, 49, 67-83.

Jakolev. V.; Isaac, O.; Thiemer, K. and Kunde, R. (1979), Pharmacological investigations with compounds of chamomile. II. New investigations on the antiphlogistic effects of (-)- a-bisabolol and bisabolol oxides. Planta Medica, 35, 125-140.

Larzelere, M. M. and Wiseman, P. (2002), Anxiety, depression, and insomnia. Primary Care, 29, 339-360.

Lepley, D. M.; Li, B.; Birt, D. F. and Pelling, J. C. (1996), The chemopreventive flavonoid apigenin induces G2/M arrest in keratinocytes. Carcinogenesis, 17, 2367-2375.

Leung, A. Y. and Foster, S. (1998), Matricaria chamomilla. In: Encyclopedia of common natural ingredients. New York: A. Wiley-Interscience. pp. 164A.

Li, B.; Pinch, H. and Birt, D. F. (1996), Influence of vehicle, distant topical delivery, and biotransformation on the chemopreventive activity of apigenin, a plant flavonoid, in mouse skin. Pharmaceutical Research, 13, 1530-1534. 
Liang, Y. C.; Huang, Y. T.; Tsai, S. H.; Lin-Shiau, S. Y.; Chen, C. F. and Lin, J. K. (1999), Suppression of inducible cyclooxygenase and inducible nitric oxide synthase by apigenin and related flavonoids in mouse macrophages. Carcinogenesis, 20, 1945-1952.

Lomas, D. A.; Ip, M.; Chamba, A. and Stockley, R. A. (1991), The effect of in vitro and in vivo dexamethasone on human neutrophil function. Agents Actions, 33, 279-285.

Madisch, A.; Melderis, H.; Mayr, G.; Sassin, I. and Hotz, J. (2001), A plant extract and its modified preparation in functional dyspepsia. Results of a double-blind placebo controlled comparative study. Zeitschrifit fur Gastroenterologie, 39, 511-517.

Maiche, A. G.; Grohn, P. and Maki-Hokkonen, H. (1991), Effect of chamomile cream and almond ointment on acute radiation skin reaction. Acta Oncologica, 30, 395-396.

Mann, C. and Staba, E. (1986), The chemistry, pharmacology, and commercial formulations of chamomile. In: Craker, L. E. and Simon, J. E. (Eds.). Herbs, spices and medicinal plants: recent advances in botany, horticulture, and pharmacology. Arizona: Oryx Press. v. 1. pp. 235-280.

Miller, T.; Wittstock, U.; Lindequist, U. and Teuscher. E. (1996), Effects of some components of the essential oil of chamomile, Chamomilla recutita, on histamine release from rat mast cells. Planta Medica, 62, 60-61.

Mills, S. and Bone, K. (2000), Principles and practice of phytotherapy - modern herbal medicine. Edinburgh: Churchill Livingstone. pp. 643.

Muller, A. A.; Reiter. S. A.; Heider, K. G. and Wagner. H. (1999), Plant-derived acetophenones with antiasthmatic and antiinflammatory properties: inhibitory effects in chemotaxis, right angle scatter and actin polimeryzation of polymorphonuclear granulocytes. Planta Medica, 65, 590-594.

Rekka, E. A.; Kourounakis, A. P. and Kourounakis, P. N. (1996), Investigation of the effect of chamazulene on lipid peroxidation and free radical processes. Research Communication in Molecular Pathology and Pharmacology, 92, 361-364.

Safayhi, H.; Sabieraj, J.; Sailer, E-R. and Ammon, H. P. T. (1994), Chamazulene: an antioxidant-type inhibitor of leukotriene B4 formation. Planta Medica, 60, 410-413.

Salamon, I. (1992), Production of chamomile, Chamomilla recutita (L.) Rauschert, in Slovakia. Journal of Herbs, Spices, and Medicinal Plants, 1, 37-45.

Scalia, S.; Giuffreda, L. and Pallado, P. (1999), Analytical and preparative supercritical fluid extraction of chamomile flowers and its comparison with conventional methods. Journal of Pharmaceutical and Biomedical Analysis, 21, 549-558.
Shen, Y. C.; Chou, C. J.; Chiou, W. F. and Chen, C. F. (2001), Anti-inflammatory effects of the partially purified extract of radix Stephaniae tetrandrae comparative studies of its active principles tetrandrine and fangchinoline on human polymorphonuclear leukocyte functions. Molecular Pharmacology, 60, 1083-1090.

Stingeni, L.; Agea, E.; Lisi, P. and Spinozzi, F. (1999), T-lymphocyte cytokine profiles in Compositae airborne dermatitis. British Journal of Dermatology, 141, 689-693.

Tubaro, A.; Zilli, C.; Redaelli, C. and Della Loggia, R. (1984), Evaluation of antiinflammatory activity of a chamomile extract topical application. Planta Medica, 50, 359.

Viola, H.; Wasowski, C.; Levi de Stein, M.; Wolfman, C.; Silveira, R.; Dajas, F.; Medina, J. H. and Paladini, A. C. (1995), Apigenin, a component of Matricaria recutita flowers, is a central benzodiazepine receptors-ligand with anxiolytic effects. Planta Medica, 61, 213-216.

Weizman, Z.; Alkrinawi, S.; Goldfarb, D. and Bitran. C. (1993), Efficacy of herbal tea preparation in infantile colic. Journal of Pediatrics, 122, 650-652.

Zentay, Z.; Sharaf, M.; Qadir, M.; Drafta, D. and Davidson D (1999), Mechanism for dexamethasone inibition of neutrophil migration upon exposure to lipopolysaccharide in vitro: role of neutrophil interleukin-8 release. Pediatric Research, 46, 406-410.

Received: December 20, 2004; Revised: July 04, 2005; Accepted: March 30, 2006. 